\title{
$\mathrm{Mo}: \mathrm{Na} / \mathrm{Mo}$ 이중층 구조 두께에 따른 태양전지 후면전극의 조직 및 전기적 특성
}

\author{
신윤학 ${ }^{\dagger}$ 김명한
}

충북대학교 신소재공학과

\section{Morphology and Electrical Properties of Back Electrode for Solar Cell Depending on the Mo: Na/Mo Bilayer Thickness}

\author{
Younhak Shin ${ }^{\dagger}$ and Myunghan Kim \\ Department of Advanced Materials Engineering, Chungbuk National University, Chungbuk, Cheongju 310, Korea
}

(2013년 8월 5일 접수 : 2013년 8월 22일 최종수정 : 2013년 8월 27일 채택)

\begin{abstract}
Mo-based thin films are frequently used as back electrode materials because of their low resistivity and high crystallinity in CIGS chalcopyrite solar cells. Mo:Na/Mo bilayer thin films with $1 \mu \mathrm{m}$ thickness were deposited on soda lime glass by varying the thickness of each layer using dc-magnetron sputtering. The effects of the Mo:Na layer on morphology and electrical property in terms of resistivity were systematically investigated. The resistivity increased from $159 \mu \Omega \cdot \mathrm{cm}$ to $944 \mu \Omega \cdot \mathrm{cm}$; this seemed to be caused by increased surface defects and low crystallinity as the thickness of Mo:Na layer increased from $100 \mathrm{~nm}$ to $500 \mathrm{~nm}$. The surface morphologies of the Mo thin films changed from a somewhat coarse fibrous structures to irregular and fine celled structures with increased surface cracks along the cell boundaries as the thickness of Mo: Na layer increased. Na contents varied drastically from $0.03 \%$ to $0.52 \%$ according to the variation of Mo:Na layer thickness. The change in $\mathrm{Na}$ content may be ascribed to changes in surface morphology and crystallinity of the thin films.
\end{abstract}

Key words $\underline{\mathrm{Na}}, \mathrm{Mo}$, photovoltaics, back electrode.

\section{1. 서 론}

$\mathrm{Cu}(\mathrm{In}, \mathrm{Ga}) \mathrm{Se}_{2}(\mathrm{CIGS})$ 박막은 직접천이형 반도체로서 광흡 수계수가 $1 \times 10^{5} \mathrm{~cm}^{-1}$ 로 가장 높으며, 여기에 $\mathrm{Al}, \mathrm{S}$ 등을 첨가하면 광학적 밴드갭을 $1 \mathrm{eV} 2.7 \mathrm{eV}$ 로 폭넓은 범위로 조절이 가능하다. ${ }^{1)} \mathrm{CuInSe}_{2}(\mathrm{CIS})$ 박막은 직접천이형 반 도체로 광흡수계수가 $1 \times 10^{5} \mathrm{~cm}^{-1}$ 로 가장 높으며, 여기에 $\mathrm{In}$ 자리 일부에 $\mathrm{Ga}$ 이나 $\mathrm{Al}$ 을, $\mathrm{Se}$ 대신 일부자리에 $\mathrm{S}$ 을 첨가하면 광학적 밴드갭을 $1.05 \mathrm{eV} 2.43 \mathrm{eV}$ 로 폭넓게 범 위를 조절할 수 있다. ${ }^{1)}$ 또한 열적으로 매우 안정하기 때 문에 전지가 장시간 빛에 노출되었을 경우에도 효율감 소를 거의 보이지 않으며, 내습성도 우수한 것으로 보 고되고 있다. 이렇듯 태양전지의 광흡수층으로 우수한 특 성을 가지고 있는 $\mathrm{CIGS}$ 박막은 $\mathrm{CdS}$ 및 $\mathrm{ZnO}$ 와의 이종 접합(hetero junction)형태로써 태양전지 제조가 가능하며,
현재 국내외에서 Glass/Mo/CIGS/CdS/ZnO CuInGaSe 박 막형 태양전지는 실리콘계 태양전지의 대체물질로 집중적 인 연구개발이 이루어지고 있다.,3)

이러한 CIGS 박막은 다원화합물이기 때문에 제조공정 이 매우 까다롭다. 물리적인 박막제조방법으로는 동시진 공증발(co-evaporation)법 및 스퍼터링, 화학적인 방법으 로는 프린팅 및 전착(electrodeposition)이 적용되고 있다.

본 연구에서는 스퍼터링법에 의한 방식으로 소다라임 글라스 기판으로부터 공급되는 $\mathrm{Na}$ 에 추가적으로 $\mathrm{Na}$ 이 1 wt.\% 도핑된 $\mathrm{Mo}$ 과 순수 $\mathrm{Mo}$ 타겟을 이용하여 bilayer 형태로 $1 \mu \mathrm{m}$ 두께를 증착시킨 후 $\mathrm{Na}$ 이 도핑된 $\mathrm{Mo}$ 층의 두께와 순수 $\mathrm{Mo}$ 층 두께의 변화에 따라 소다라임글라스 기판에서 함유하고 있는 $\mathrm{Na}$ 및 하부층인 $\mathrm{Na}$ 이 도핑된 $\mathrm{Mo}$ 층에서의 $\mathrm{Na}$ 의 농도변화에 따른 순수 $\mathrm{Mo}$ 층에 끼치 는 영향을 알아보기 위해 면저항, 화학적조성, 조직, 표

\footnotetext{
${ }^{\dagger}$ Corresponding author

E-Mail : jedoki@naver.com (Y. H. Shin, Chungbuk Univ.)
}

(C) Materials Research Society of Korea, All rights reserved.

This is an Open-Access article distributed under the terms of the Creative Commons Attribution Non-Commercial License (http://creativecommons.org/licenses/by-nc/3.0) which permits unrestricted non-commercial use, distribution, and reproduction in any medium, provided the original work is properly cited. 
면형상, 조도 및 결정구조를 조사 분석하였다.

\section{2. 실험 방법}

소다라임글라스 기판을 $25 \times 25 \times 0.4 \mathrm{~mm}$ 로 사용하였 고, $\mathrm{Mo}$ 의 이중층(bilayer)을 증착하기 전 기판의 이물질 을 제거하기 위하여 초음파 세척을 한 후 건조하였다. 이중층은 $1 \mathrm{wt} . \% \mathrm{Na}$ 도핑된 $\mathrm{Mo}$ 타겟과 $99.99 \%$ 의 고 순도 $\mathrm{Mo}$ 타겟을 사용하였다. 진공챔버내의 초기진공은 $5.0 \times 10^{-6} \mathrm{Torr}$ 이하 이었고, $\mathrm{Ar}$ 분압은 $3.0 \times 10^{-3} \mathrm{Torr}$ 로 일정하게 유지하였으며, 타겟과 기판 사이의 거리는 $5 \mathrm{~cm}$ 로 간격을 두었다. 기판은 박막을 균일하게 증착시키기 위해 $10 \mathrm{rpm}$ 으로 회전을 하였다. 후면전극의 표면저항은 4단자법(AIT사의 CMT-100MP)를 이용하여 5개 포인트 를 측정하여 평균값을 표현하였으며, 후면전극의 국부적 $\mathrm{Na}$ 의 농도를 확인하기 위해 XRF(Rigaku사의 ZSX400) 를 이용해 10 포인트를 측정하여 평균값을 나타내었다. 표 면형상 및 단면형상은 FE-SEM(Carl Zeiss사의 supra6)
을 이용하여 두께 및 구조적 형상을 관찰하였으며, 표 면조도 형상 및 조도측정에는 $\mathrm{AFM}(\mathrm{Veeco}$ 사의 Dimension $\mathrm{V})$ 가 사용되었고, 결정구조 분석은 $\mathrm{XRD}(\mathrm{Rigaku}$ 사 의 SmartLab)을 이용하였다.

\section{3. 결과 및 고찰}

\section{1 이중층구조의 두께 변화에 따른 Mo 박막의 조직}

Mo 박막은 $3.0 \times 10^{-3} \mathrm{Torr}$ 의 $\mathrm{Ar}$ 의 일정분압에서 $1 \mathrm{wt} . \%$ $\mathrm{Mo}: \mathrm{Na}$ 과 순수 Mo 박막의 두께 변화에 따른 표면의 $\mathrm{SEM}$ 사진을 Fig. 1(a f)에 나타내었다. (a)에서 Mo 박 막표면은 짧고 굵은 섬유 형상으로 존재하고 있으며, 이 는 Mo:Na 박막의 두께가 증가함에 따라 (b f) 미세한 불규칙 셀 형상으로 변화하고, 셀 경계면을 따라 곳곳 에 크랙이 산재되어 있는 것을 알 수 있다. 크랙은 $\mathrm{Mo}$ : $\mathrm{Na}$ 박막의 두께가 증가할수록 크고 깊게 형성되었으며, 이는 $\mathrm{Na}$ 의 첨가에 의해 $\mathrm{Mo}$ 의 입자 성장에 불순물로 작 용하여 방해한다고 볼 수 있으며, $\mathrm{Mo}$ 의 스퍼터링시 $\mathrm{Ar}$
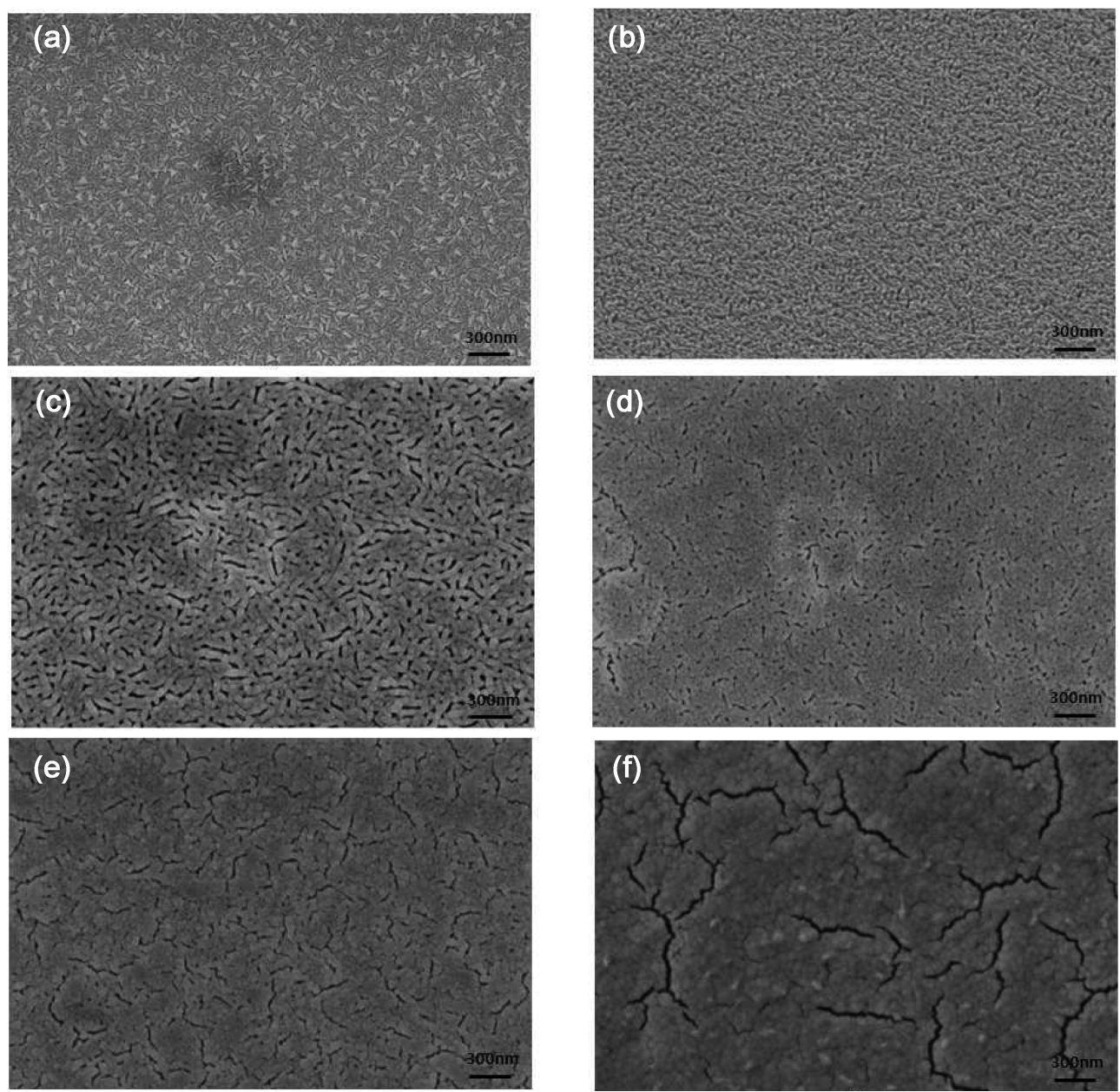

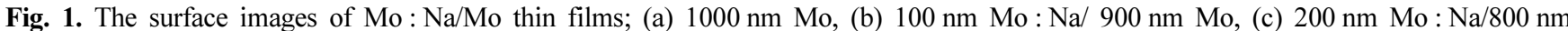
Mo, (d) $300 \mathrm{~nm} \mathrm{Mo:} \mathrm{Na/700} \mathrm{nm} \mathrm{Mo,} \mathrm{(e)} 400 \mathrm{~nm} \mathrm{Mo:} \mathrm{Na/600} \mathrm{nm} \mathrm{Mo,} \mathrm{(f)} 500 \mathrm{~nm} \mathrm{Mo:} \mathrm{Na/500} \mathrm{nm} \mathrm{Mo.}$ 
분압을 낮추어 $\mathrm{Mo}$ 층의 밀도를 증가시키는 방법으로 크 랙의 제어가 가능하나 $\mathrm{Ar}$ 분압을 너무 낮추면 기판과의 접착력이 불량해지기 때문에 상대적 조절이 필요하다. Fig. 2(a f)는 Mo: Na과 순수 Mo 박막의 두께변화에 따 른 박막표면의 $\mathrm{AFM}$ 이미지 이다. 여기서 $\mathrm{Mo}: \mathrm{Na}$ 박 막의 두께가 $200 \mathrm{~nm}$ 까지는 (a c) 표면조도의 변화가 거 의 없었으나 (c)의 $300 \mathrm{~nm}$ 를 기점으로 조도값이 낮아진 후 증가하는 경향을 볼 수 있다. Fig. 3에 Mo 표면조도 (Ra)를 측정한 결과를 도식화 하였다. $200 \mathrm{~nm}$ 까지는 3.39 3.55의 좁은 범위내에서 변화하고 있고, $300 \mathrm{~nm}$ 에 서는 3.03의 다소 낮은 조도값을 나타내고 있다. 400 $500 \mathrm{~nm}$ 까지는 각각 4.22 및 4.95 로 표면조도 값이 급 격히 증가하는 것을 볼 수 있다. 이는 기판의 표면조도 가 클 경우 나타날 수 있는 CIGS박막 결정립의 미세 화, 기판으로부터 CIGS 박막으로의 확산 및 분로(shunt path)에 따른 태양전지의 성능저하의) 요인으로 될 가능 성이 있을 것으로 사료된다.
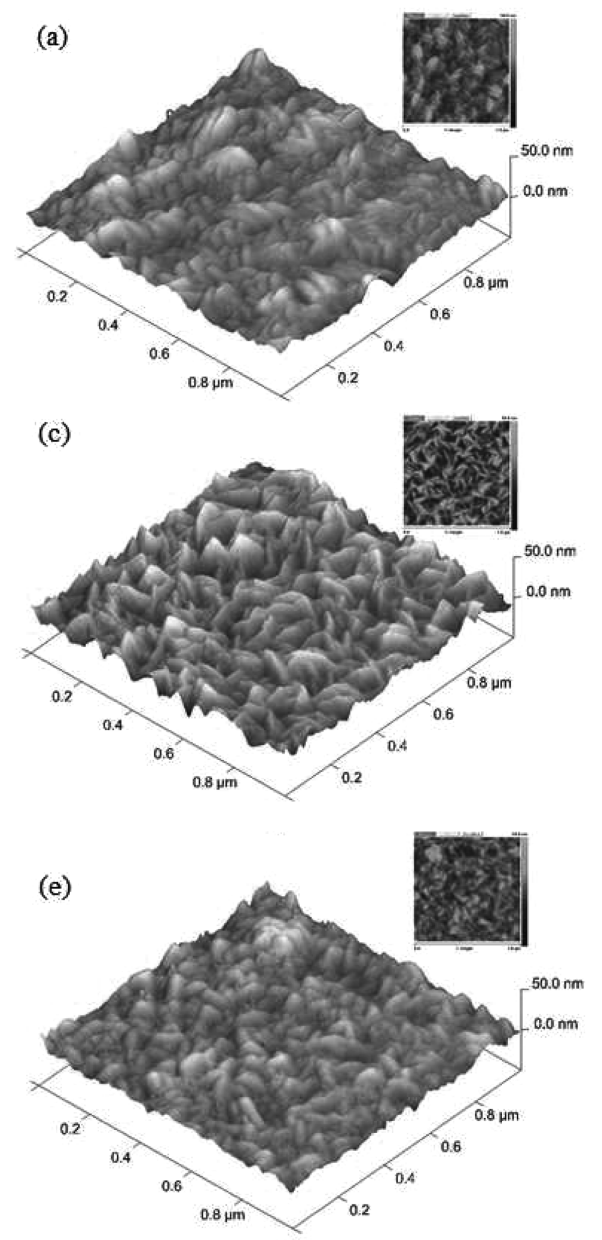

Fig. 4(a e)는 $\mathrm{Mo}: \mathrm{Na}$ 층과 순수 $\mathrm{Mo}$ 층으로 형성된 후 면전극을 $\mathrm{FIB}$ 로 식각한 단면의 $\mathrm{SEM}$ 이미지를 보여주고 있다. 박막단면 관찰결과 수직방향의 주상정이 잘 발달 되어 있는 것을 볼 수 있었다. 특히 상부층의 순수 $\mathrm{Mo}$ 박막은 $\mathrm{Mo}: \mathrm{Na}$ 박막에 비해 치밀하게 형성되어 주상정 구조로 성장하는 형상을 관찰할 수 있으며, $\mathrm{Mo}: \mathrm{Na}$ 박 막은 두께가 두꺼워질수록 크랙이 나타나는 형상을 관 찰할 수 있다. 이는 표면의 크랙형성과 상관관계가 있 는 것으로 보여지며, $\mathrm{Na}$ 의 함량이 증가하거나 박막내부 에 $\mathrm{O}, \mathrm{H}, \mathrm{Ar}$ 등의 침투로 인해 발생되는 것으로 알려져 있다. ${ }^{5}$

Fig. 5는 $\mathrm{Mo}: \mathrm{Na}$ 박막의 두께가 증가함에 따른 $\mathrm{Mo}$ 박 막의 XRD 분석 결과이다. Mo 박막의 우선성장방향인 (110)면의 피크는 $2 \theta=40^{\circ}$ 부근에서 관찰되었으며(JCPDS421120), 이차상인 (211)면도 일부 나타나고 있다. 이차 상은 우선성장면이 강하게 나타날수록 비례하여 나타나 고 있으며, 이는 Mo 박막이 입방체 결정구조를 가지고
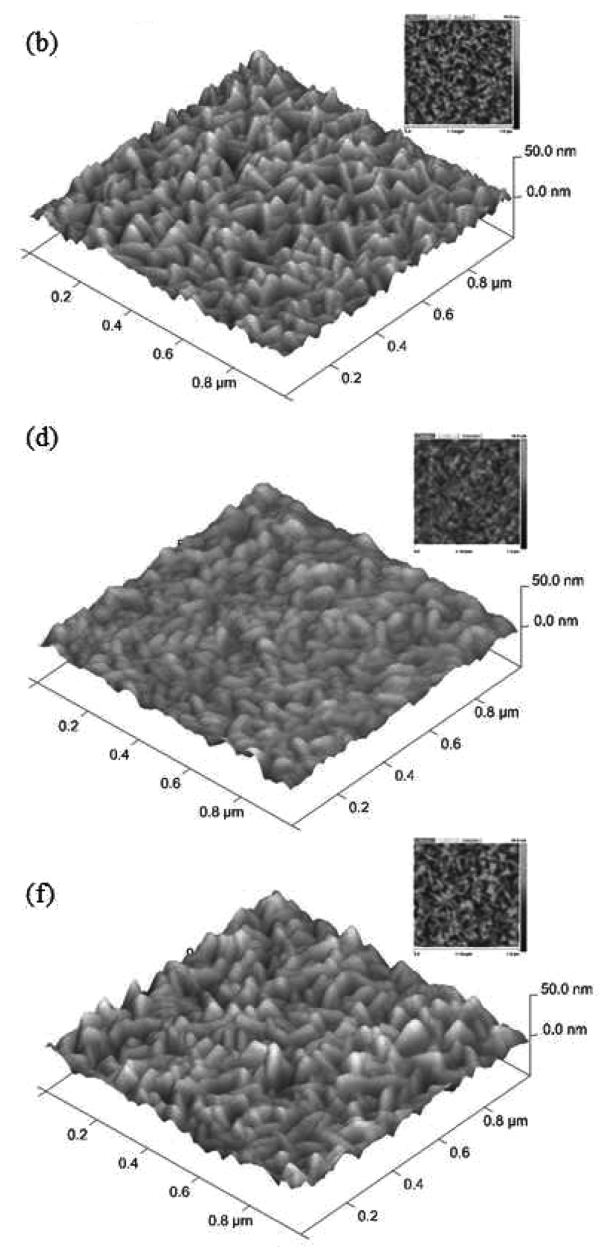

Fig. 2. The AFM images of Mo : Na/Mo thin films; (a) $1000 \mathrm{~nm} \mathrm{Mo,} \mathrm{Ra=3.39nm} \mathrm{(b)} 100 \mathrm{~nm}$ Mo : Na/900 nm Mo, Ra=3.43 nm, (c) $200 \mathrm{~nm}$ Mo : Na/800 nm Mo, Ra $=3.55 \mathrm{~nm}$, (d) $300 \mathrm{~nm} \mathrm{Mo} \mathrm{:} \mathrm{Na/700} \mathrm{nm} \mathrm{Mo,} \mathrm{Ra=3.03} \mathrm{nm,} \mathrm{(e)} 400 \mathrm{~nm} \mathrm{Mo:} \mathrm{Na/600} \mathrm{nm} \mathrm{Mo,} \mathrm{Ra=4.22} \mathrm{nm,} \mathrm{(f)} 500 \mathrm{~nm}$ Mo : Na/500 nm Mo, Ra $=4.95 \mathrm{~nm}$. 


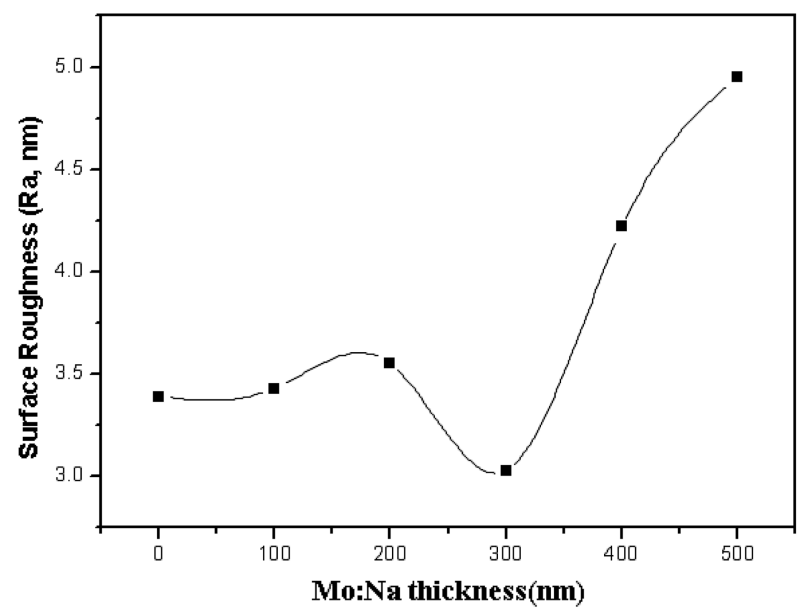

Fig. 3. The surface roughnesses of Mo thin films according to Mo : $\mathrm{Na}$ thickness.

성장한 것을 의미하고, 이는 추후 CIGS 박막이 (112)면 으로 성장하기 용이한 결정구조로 성장되었음을 나타내 기도 한다. 또한 이는 Fig. 1 및 4의 박막의 표면 형상 과 단면의 분석결과와 일치하는 것을 알 수 있다. Mo: $\mathrm{Na}$ 박막의 두께가 $200 \mathrm{~nm}$ 와 $300 \mathrm{~nm}$ 에서 우선성장면이 강하게 나타나고, 반치폭(FWHM) 또한 작아지고 있다. 이는 $\mathrm{Mo}: \mathrm{Na}$ 의 함유량에 따라 상부층인 $\mathrm{Mo}$ 박막으로 확산되어 결정성에 영향을 끼치는 것으로 판단되어지며, CIGS 광흡수층 내의 적정한 $\mathrm{Na}$ 농도가 $4 \times 10^{20}$ atoms/ $\mathrm{cm}^{3}$ 의 범위로 광흡수층에 이 정도의 $\mathrm{Na}$ 농도를 공급하기 위해서 필요한 $\mathrm{Na}$ 함량을 가진 $\mathrm{Mo}: \mathrm{Na}$ 층이 요구되어 진 다. ${ }^{6} \mathrm{Mo}$ 의 결정구조는 $\mathrm{CIGS}$ 광흡수층의 결정 성장에 많 은 영향을 주게 되며, 특히 우선성장면인 (110) 면으로 성장된 Mo 박막은 CIGS 박막의 우선성장 방향인 (112)

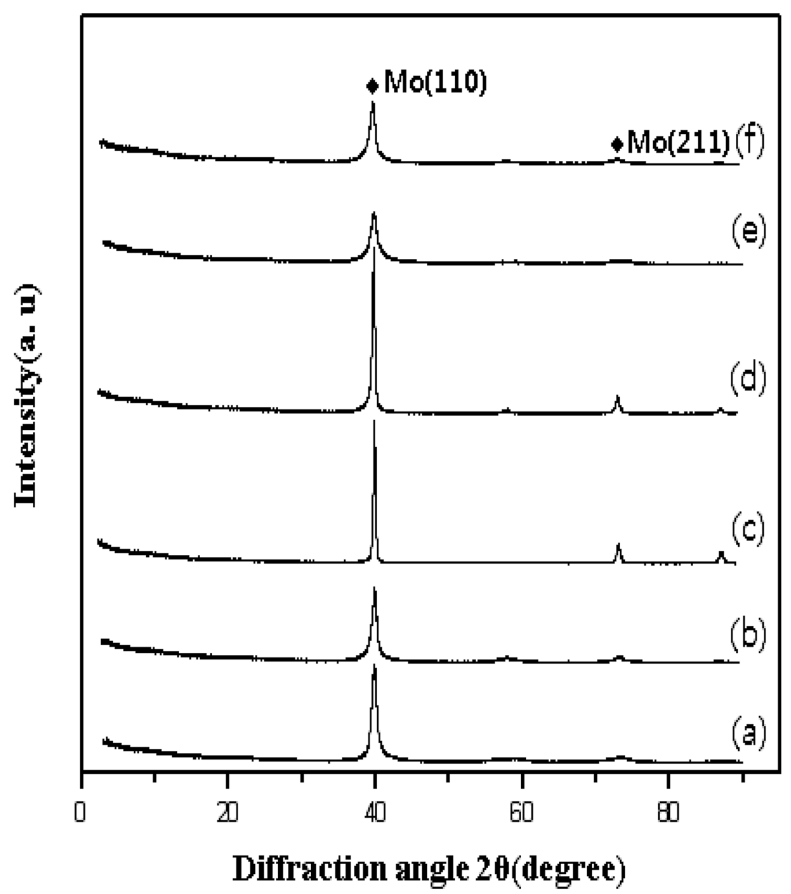

Fig. 5. XRD patterns of Mo : Na/Mo thin films deposited by DC magnetron sputtering; (a) $1000 \mathrm{~nm} \mathrm{Mo}$, (b) $100 \mathrm{~nm} \mathrm{Mo}: \mathrm{Na} / 900 \mathrm{~nm}$ Mo, (c) $200 \mathrm{~nm} \mathrm{Mo:} \mathrm{Na/800} \mathrm{nm} \mathrm{Mo,} \mathrm{(d)} 300 \mathrm{~nm} \mathrm{Mo:} \mathrm{Na/700} \mathrm{nm}$ Mo, (e) $400 \mathrm{~nm} \mathrm{Mo:} \mathrm{Na/600} \mathrm{nm} \mathrm{Mo,} \mathrm{(f)} 500 \mathrm{~nm} \mathrm{Mo:} \mathrm{Na/500} \mathrm{nm}$ Mo.

면의 성장을 촉진시키며, 2차상에 해당하는 (200) 및 (211) 등의 결정성장면은 CIGS 박막의 (112)성장을 제 한하게 된다. ${ }^{5,7)}$

Fig. 6은 질소분위기에서 $200{ }^{\circ} \mathrm{C}$ 로 30 분동안 어닐링된 $\mathrm{Mo}$ 박막의 표면을 $\mathrm{XRF}$ 로 측정한 결과값이며, 각 10 회 측정 평균값을 나타낸 것이다. 어닐링을 한 이유는 도
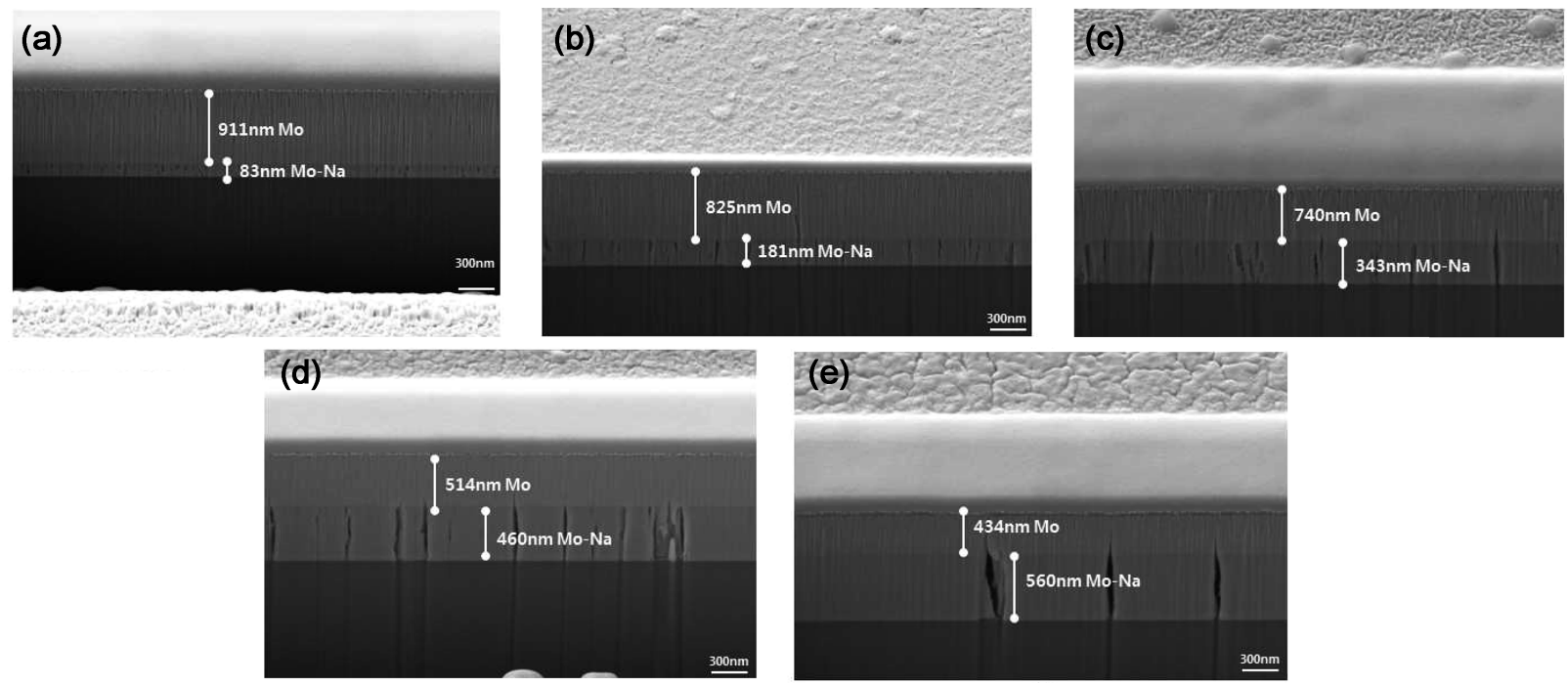

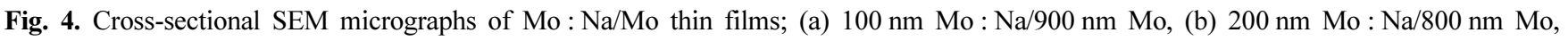

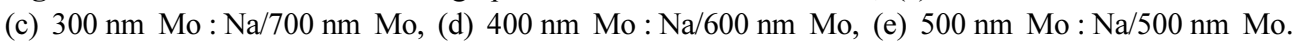




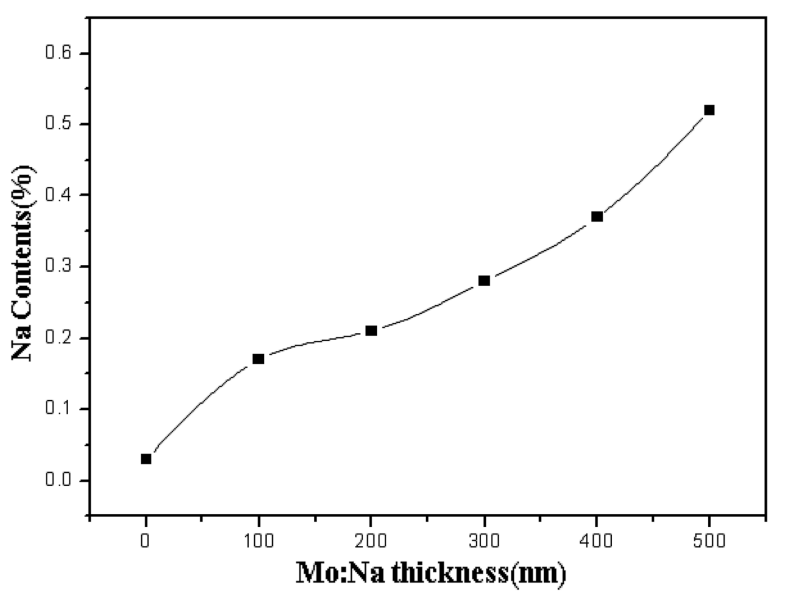

Fig. 6. Na contents of Mo thin films according to Mo : Na thickness.

핑된 $\mathrm{Na}$ 의 확산을 통해 상부층인 $\mathrm{Mo}$ 박막의 결정성에 영향을 주기 위함이다. $\mathrm{Na}$ 의 농도는 $\mathrm{Mo}$ 박막만 $1 \mu \mathrm{m}$ 로 형성된 막에서도 $0.03 \%$ 의 함유량을 분포하고 있으 며, 이는 기판이 소다라임글라스로 $\mathrm{Na}$ 이 기판 내부에 함유되어 있어 여기서 기인한 것으로 판단된다. $\mathrm{Na}$ 이 도핑된 $\mathrm{Mo}$ 박막의 두께가 두꺼울수록 Mo 박막 표면 의 $\mathrm{Na}$ 함유량이 $0.17 \sim 0.52 \%$ 로 나타남을 알 수 있으며, $\mathrm{Mo}: \mathrm{Na}$ 의 두께가 $300 \mathrm{~nm}$ 에서 $0.28 \%$ 농도분포를 나타 내었는데 이 농도가 상부층인 $\mathrm{Mo}$ 막의 낮은 표면조도 (Fig. 2 3)와 낮은 면저항 값을(Fig. 5) 갖게 해줌과 동 시에 막의 결정성장에도(Fig. 6) 영향을 주는 것으로 판 단되어 지고, $0.28 \%$ 이상의 농도에서는 $\mathrm{Mo}: \mathrm{Na}$ 막에 서의 과도한 크랙 형성에 따라 상부층인 $\mathrm{Mo}$ 층에서 영 향을 받아 막성장을 저해하는 요인으로 여겨지며, 많고 깊은 크랙형성에 따라 높은 표면조도와 높은 면저항값 을 가짐으로써 $\mathrm{Na}$ 의 농도에 따라 박막의 결정성장 및 결함발생의 원인중 하나임 을 알 수 있다. ${ }^{8)}$

\section{2 이중층구조의 두께 변화에 따른 Mo 박막의 전 기광학적 특성}

Fig. 7은 태양전지의 Mo 후면전극 제조시 $\mathrm{Mo}: \mathrm{Na}$ 박 막의 두께 변화에 따른 비저항의 변화를 나타낸 것이 다. Mo: $\mathrm{Na}$ 박막의 두께가 $300 \mathrm{~nm}$ 일 때 $159 \mu \Omega \cdot \mathrm{cm}$ 기 점으로 $\mathrm{Mo}$ 박막의 비저항 값은 선형적으로 증가하여 $500 \mathrm{~nm}$ 의 두께에서는 $944 \mu \Omega \cdot \mathrm{cm}$ 의 높은 비저항을 보였 으며, 그 원인은 다음과 같다. 우수한 Mo 박막을 성장 시키기 위해서는 적정한 $\mathrm{Ar}$ 분압과 챔버내 이물이 존재 하지 않도록 고진공 상태에서 공정을 진행해야 하며, 이 는 박막표면에 침투하는 인자를 최소한으로 해서 비저 항을 증가시키지 않는다. 이중층의 하부구조인 $\mathrm{Na}$ 이 도 핑된 $\mathrm{Mo}$ 박막내에 $\mathrm{Na}$ 이 과도하게 확산되어 상부층인 $\mathrm{Mo}$ 과 결합하면서 크랙을 형성하여 비저항의 증가를 유

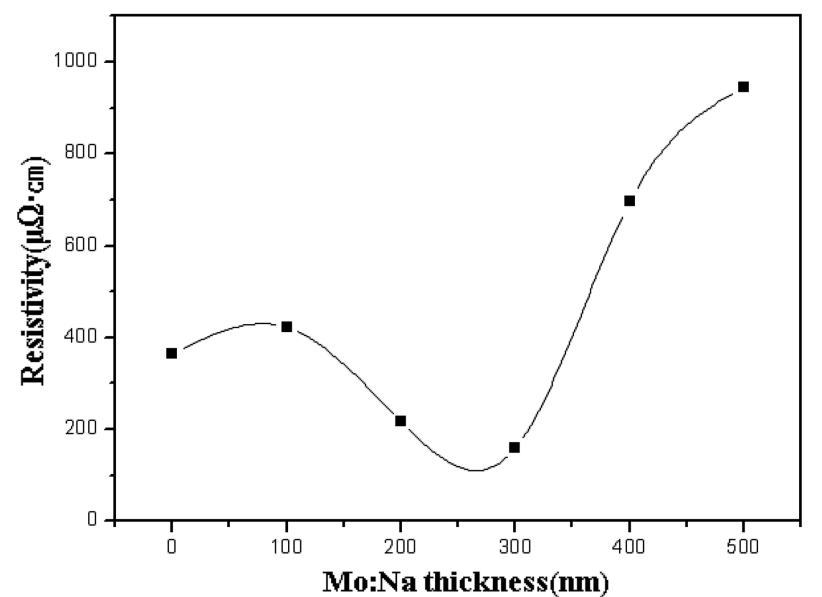

Fig. 7. Resistivities of Mo thin films according to Mo : Na thickness.

발하였으며, 또는 챔버내 존재하는 $\mathrm{O}, \mathrm{H}, \mathrm{Ar}$ 과 같은 이 물이 박막에 침투하여 표면조도 및 비저항을 증가시키 는 요인으로 판단되어지며, 실제로 표면조도와 비저항은 비례하는 경향을 보여주고 있다.

\section{4. 결 론}

우수한 결정구조와 낮은 비저항을 얻기 위한 CIGS 태 양전지용 $\mathrm{Mo}$ 후면전극의 스퍼터링 증착조건을 정립하기 위하여, $1 \mathrm{wt} . \% \mathrm{Na}$ 이 도핑된 $\mathrm{Mo}$ 박막을 $100 ~ 500 \mathrm{~nm}$ 두께로 변화를 주어 Mo 박막으로 최종 두께 $1 \mu \mathrm{m}$ 를 증 착시켜 박막의 조직 및 물성특성을 분석하였으며, 다음 과 같은 결론을 얻을 수 있었다.

1) $\mathrm{Mo}: \mathrm{Na}$ 박막의 두께 변화에 따라 Mo 박막은 $\mathrm{Mo}$ : $\mathrm{Na}$ 박막이 두꺼울수록 표면의 크랙이 커짐을 알 수 있 었다.

2) 표면조도는 0 200 nm까지는 거의 변화가 없으나 $300 \mathrm{~nm}$ 를 기점으로 조도값이 3.03 에서 4.22 및 4.95 로 증가함을 알 수 있었다.

3) 박막의 단면은 대부분의 막은 주상정 형상으로 성 장하였으나, $\mathrm{Mo}: \mathrm{Na}$ 두께가 두꺼울수록 내부 크랙이 심 해졌으며, 이는 $\mathrm{Na}$ 이 첨가되면서 $\mathrm{Mo}$ 의 입자 성장에 불 순물로 작용하여 방해한다고 볼 수 있다.

4) (110)면으로 성장된 Mo 박막은 CIGS 우선성장 방 향인 (112)면의 성장을 촉진 시킨다. $\mathrm{Mo}: \mathrm{Na}$ 막이 200 $\mathrm{nm}$ 와 $300 \mathrm{~nm}$ 두께로 형성된 $\mathrm{Mo}$ 박막의 결정구조가 (110)면이 가장 강하게 성장된다.

5) $\mathrm{Mo}: \mathrm{Na}$ 가 $300 \mathrm{~nm}$ 의 두께로 형성되었을 때 가장 낮은 비저항을 나타냈다.

따라서 $\mathrm{Mo}: \mathrm{Na}$ 의 두께가 $300 \mathrm{~nm}$ 이며, $\mathrm{Na}$ 의 농도가 $0.28 \%$ 함유되면서, $159 \mu \Omega \cdot \mathrm{cm}$ 비저항을 나타내는 박막 이 형성되어야 우수한 결정구조를 갖는 것을 알 수 있 
었으며, 추후 낮은 압력에서 높은 입자 밀도, 즉 낮은 표면저항을 기대할 수 있기 때문에 상부 $\mathrm{Mo}$ 층을 증착 시 $\mathrm{Ar}$ 분압을 조절하여 표면저항을 낮출 필요가 있다.

\section{References}

1. K. Bouabid, A. Ihlal, A Manar, A. Outzourhit and E. L. Ameziane, Thin Solid Films, 488, 62 (2005).

2. K. W. Mitchell, C. Eberspacher, J. Ermer and D. Pier, Proc. $20^{\text {th }}$ IEEE Photovoltaic Specialists Conf., 1384, (1989).

3. A. M. Gabor, J. R. Tuttle, M. A. Contreras, D. S Albin,
A. Franz, D. W. Niles, and R. Noufi, 12 ${ }^{\text {th }}$ European Photovoltaic Solar Energy Conf., 1, (1994).

4. W. K. Batchelor, I. L. Repins, J. Schaefer, M. E. Beck, Sol. Energ. Mater. Sol. Cell., 83, 67 (2004).

5. J. H. Scofield, A. Duba, D. Albin, B. L. Ballard, P. K. Predecki, Thin Solid Films, 260, 26 (1995).

6. R. J. Matson, J.E. Granata, S.E. Asher and M. R. Young, NREL, 25682, 6 (1998).

7. L. Assmann, J. C. Bernede, A. Drici, C. Amory, E. Halgand and M. Morsli, Appl. Surf. Sci., 246, 159 (2005). 8. Y. C. Lin, Y. Y. Tu and C. H. Shen, Mateials Science, 24. 514 (2013). 